\title{
Combatting the Imperativeness of Modernity in Students' Unrest: The Need to Decolonise the Minds through Ubuntu
}

\author{
Bunmi Isaiah Omodan ${ }^{1}$ \\ ${ }^{1}$ School of Education Studies, University of the Free State, South Africa \\ Correspondence: Bunmi Isaiah Omodan, School of Education Studies, University of the Free State, South Africa. \\ Received: May 23, 2020 \\ Accepted: July 2, 2020 \\ Online Published: July 3, 2020 \\ doi:10.5430/ijhe.v9n4p310 \\ URL: https://doi.org/10.5430/ijhe.v9n4p310
}

\begin{abstract}
The trajectory of students' unrest in Nigeria universities has been linked to the underside of modernity. By responding to this, the study explores conditions necessary to decolonise the mindset of university authorities and students, against modernity as an offshoot of students' unrest. Ubuntu philosophy rationalised the study while Transformative Paradigm lensed the process with the use of Participatory Action Research design. The study involved ten co-researchers, three university management staff, three students' leaders, two security personnel and two university lecturers were selected using Convenient Sampling Technique. Focus Group Discussion was employed to generate data, and the data were subjected to Conversational Analysis to make sense of the data. Students' involvement in decision-making, democratic and facilitative leadership style, were found as tools to decolonise the space of students' unrest as an underside of modernity. The reconstruction of the university system against social unrest emanating from modernity becomes expedient through Ubuntu cum decoloniality.
\end{abstract}

Keywords: students' unrest, modernity, decoloniality, ubuntuism, Nigeria universities

\section{Introduction}

University all over the world are on the verge of transformation, most especially universities in the global south, this is to say that $21^{\text {st }}$-century universities will operate better in the transformed system where modernity and modernisation in a positive direction become the order of the day. Modernity in university education bothers more on the new ways of doing things, while some conceptualised it to mean the western way of doing things (Eisenstadt, 2010; Gunn \& Vernon, 2011; Richards, 2015). The fact from these thoughts confirmed that modernity in university education brings to all stakeholders the idea of new development, new ideas, innovations, transformations, and above all, devising new ways of "doing". This, according to Stein \& Andreotti (2016), decolonisation and modernity seem to represent the same space in the operation of newness in a system because of their quest for transformation. He further argued that the duo creates and maintain a network of being, knowing, and seeking to eradicate the old ways of "doing." This is to justify that modernity is not in its original intention possess any threat to the university system and its operation. But the observation and experience exist that modernity seems to have been misunderstood and or misinterpreted to be an absolute right and privilege without border. The openness of transformational modernity within universities in my argument has been taken for granted by the university stakeholders, such as; students, staff, and the university authorities, which had exposed the system to various kinds of management approaches such as Machiavellianism (Omodan, 2019). This kind of modernity as exemplified by the university stakeholders are; the students believe that we are in the modern world where they have absolute right and privilege to everything. On the other hand, the managers feel that they also possess the power to manage, dictate, take a decision and ameliorate on behalf of students, even without their consents (Lassoued, Awad \& Guirat, 2020; Hallo, Nguyen, Gorod \& Tran, 2020).

This misguided modernity in Nigerian Universities has led to various social unrests between the duo (Fomunyam, 2017; Akparep, 2019) ranging from dichotomies between and among staff unions, university authorities, and the students' populace (Taiwo, 1999; Amadi and Precious, 2015; Sishi, 2016). These unrests, according to Amadi and Precious (2015), had caused an imbalance in the budgetary allocation to university and have engendered economics repercussions for the universities and the country at large. This is to confirm that the lacuna created by the trajectory of modernity in the university system had caused more harm than good because students' oriented crises have been linked to misunderstanding as a result of high handedness of university authorities toward issues that concern students while students on their angle also believed that they have right to "do" and "undo". These actions and 
inactions of the stakeholders are traceable to modernity that gave rise to a total implementation of student rights to fight their perceived enemies. Though, there seems lapses and managerial deficiencies on the part of university authorities to address the issues using various strategies postulated by scholars, such as collaborative governance, the involvement of students in decision-making, threat assessment plan, university autonomy, and adequate funding, among others (Weeramunda, 2008; Gyan \& Tandoh-Offin, 2014; Ferdinand, 2017; Government of Papua New Guinea, 2017). My observation and literature showed that despite the concerted efforts made by university authorities to ensure that the university system in Nigeria operates in a peaceful atmosphere, students' unrest seems to be on the increase.

Students unrest caused as a result of misplacement of priority between students and university authorities in Nigeria Universities includes but not limited to the crisis that erupted in the University of Ado Ekiti, in May 2009, August 2011, and also 2014. These unrests were caused by power differentials between the two critical stakeholders where university authorities took decisions unilaterally, and students in their own believed even think that the university did not recognise their rights and privileges. I witnessed these crises as an undergraduate student in the said university, and because of the superiority complex between the duo, the issues degenerated into unrest that led to the destruction of lives and properties (Fomunyam, 2017; Akparep, 2019) Not only that, the university aims and objectives were shortchanged because the university was closed down many times between 2009 to 2014. The similar students' unrest also took place at Obafemi Awolowo University, Ladoke Akintola University, Lagos State University, University of Ibadan, among others (Etadon, 2013; Odu, 2013; Premium Times, 2017). From the above analysis, it becomes imperative to sort for solutions by exploring possible conditions that could be used to decolonise the social unrest in Nigeria universities. This decoloniality may only explore decoloniality of the minds, which, according to Oelofsen (2015), is one of the characteristics needed to decolonise the university system.

Since the problem of students' unrest has been linked to modernity in the university system, the need for decoloniality in this analysis, therefore, is a pointer to social rejuvenation and transformation of the understudy. This is in line with the argument of Mignolo and Escobar (2013) that decoloniality is an approach that exposes the leftover of Eurocentric modernity, which they also viewed as coloniality. I join my belief in the same line to say that modernity, as demonstrated in Nigeria universities, could be viewed as coloniality. That is, there is no modernity without coloniality. Coloniality is a power structure that survives the end of direct colonialism and continues to sustain asymmetrical power relations and conceptions of humanity through hierarchisations (Ndlovu, 2013). In this study, coloniality and modernity are viewed to mean the same thing, though scanty literature exists in the field of university modernity cum coloniality. However, the de-colonial approach is presented to deface the leftover of modernity/coloniality as an invisible power, social and economic structure, and epistemological design, to challenge the Euro-North Ameri-centric modern world (Ndlovu-Gatsheni, 2015). In my view, decoloniality is an epistemic site to extricate (ex)-colonised people from the coloniality of the mind and its marginalised space.

The decoloniality approach to university operations is imminently possible and needed in what we see now in the academics and how we define the purpose and character of universities as massive institutions that require dexterous management and scholarly approaches (Keet, Sattarzadeh \& Munene, 2017). Decoloniality exposes the invisibility of power relations of coloniality among the university stakeholders into visibility. Therefore, there must be ways to make the present de-colonial rhetoric find a practical solution within university education and to safeguard it as a productive angle to engage with the transformation of our universities for the purpose of achieving peace and peaceful coexistence among stakeholder (Keet, Sattarzadeh \& Munene, 2017). To achieve this, the importance of the mindset can never be underrated.

From the observations regarding the position of students' unrest in Nigeria universities, one could assume that the mindset of students is yet to be decolonised. This is why there is always a series of agitations from them from time to time. They believed that the only way to fight and or agitate for their right is when they foment trouble and cause unrest in the universities. This is evident in their usual slogan "Aluta Continua, Victoria Ascerta," which means that struggle continues until victory is certain. One could then say that the slogan indicates that there must always be issues to fight for at all times. With this, it is logical to conclude that there is an urgent need to change this mindset from Nigerian students. This is in line with the conclusion of Gertzel (2015) that decoloniality is meant to remake the world in such a way that the enslaved, colonised, and exploited people can regain their ontological density, voice, land, history, knowledge, and power. On the side of university authorities in Nigeria, perceptions also exist that they are yet to desist from the old ways of managing human capital with the illusion that they are superior to students, thereby making unilateral decisions about students' welfare without involving them in the process. From these arguments, one could trace these actions of the duo to the post-colonial and military dictatorship regime in Nigeria where leaders are rulers and followers become trouble makers. However, these regimes seem to have left the 
university system without harmonising their power politics by disarming students' knowledge and their thinking towards peace. Taken from this vacuum, the place of "Ubuntuism" is not negotiable.

\subsection{Theorising Ubuntu as a Tool to Decolonising Students' Unrest}

Ubuntu, as African philosophy, over the years, has been used as a synonym to the African way of life, which in the coinage of Mokgoro (1998), Omodan and Dube (2020) is Africanism. This philosophy originated within ancient Africa communities/villages where diverse human beings lived together in harmony, for the greater benefit of society despite their diversities (Omodan, 2019), and from African idioms such as 'Motho ke motho ka batho' and 'Umuntu ngumuntu ngabantu' which means "a person is a person through others" and "I am because we are" (Ramose, 1999; Goduka, 2000; Lefa, 2015; Arthur, Issifu \& Marfo, 2015). Arthur et al. (2015) further contemplate the concept of Ubuntu by linking it to the way of ensuring unity among people in the rural setting, that is, Ubuntu is linked to indigenous ways of managing or resolving conflicts within and among people (Swanson, 2008). This is to argue that Ubuntu does appear to people depending on their situation and the sociality surrounding the people (Anderson, 2003). In the exploration of Tutu (1990), one could conclude that Ubuntu is a way of life that preaches togetherness and unity among people. This is deduced to mean that "Ubuntuism" is an agent of honesty, love, cooperation, openness, and "collaborative-ness" (Omodan, 2019; Omodan \& Tsotetsi, 2019, Tsotetsi \& Omodan, 2020).

This is to say that people with Ubuntu are naturally "Humane" (Swanson, 2008) and could evidently produce peaceful relationships leading to total tranquillity. That is, Ubuntu produces friendliness, daringness, and compassionateness towards humanity (Goduka, 2000). From these analyses, one could conclude that the underside of modernity in the university system could be decolonised through "ubuntuism" because it promotes mutual and friendly ways of interrelatedness. In the same vein, Ubuntu is relevant to maintain peace and tranquillity in the university system or between the students and university authorities because its assumptions practically recommend cooperation and "collaborative-ness" devoid of competition and disagreement that could result into instability. In this mantra, decolonisation of the mind suffixes to compliment the principles of Ubuntu by creating a participatory system that enables students and authorities to share ideas towards university productivity irrespective of all ancient/colonial and past "dislike-ness" among the university stakeholders. The use of Ubuntu as a tool to decolonise the space of unrest in university as a result of the leftover of coloniality/modernity, therefore bend of the Ubuntu that helps to create pleasant relationships among/within people in the universities.

This is plausibly evidenced in the fact that Ubuntu placed more emphasis on the recognition of students by the university authority with adequate respect for their rights and privileges. By doing this, everyone is made to connect for productivity's sake (Marfo, 2015). In consonance, Ubuntu is an appropriate philosophy that appeases peoples' minds towards reconciliation, prevailed in the participants' minds before and during unrest (Faure, 2000). Therefore, in order to decolonise the minds of the university stakeholders towards managing students' unrest as an offshoot of modernity. Ubuntu, like an Africanised way of "doing," plays a pivotal role in ensuring that all parties are mindlessly concerted towards crisis prevention and reconciliation. In lieu of the above, the study explores possible conditions that are necessary for the decolonisation of the mind against modernity as an underside of students' unrest in the university system. Hence, the vacuum of modernity will, however, be subjected to empirical investigation by answering the following question.

\subsection{Research Question}

In order to respond to the problem of modernity as an offshoot of students' unrest in universities in Nigeria, the following question will pilot the study;

1. How can the imperativeness of modernity as a propeller of students' unrest in the university system be decolonised through Ubuntu?

\section{Methodology}

In order to maintain the trend of transformation from the modernity to decoloniality, the Transformative Paradigm (TP) is used to lens the study. The transformative paradigm is appropriate because the investigation is aimed to transform social space (Mertens, 2015), of university education from consistent students' unrest to a peaceful social system that works. In the same vein, the use of transformational theories, such as; critical theories such as; post-colonial discourses, feminist theories, race-specific, neo-Marxist theories, and Ubuntu are tools for emancipation also give way to easy transformation with the use of Participatory Action Research (PAR) as a research design (Mertens, 2005; Dube, 2016; Gaus, 2017). PAR was adopted to design the study because the process of transformation involves participation and equality between the researcher and the researched (Khan \& Chovanec 2010). That is, PAR and TP deal with social issues (MacDonald, 2012). PAR is therefore appropriate because the 
study aims to change the issue of social menace for better in the universities. This is in line with the argument of MacDonald (2012) that PAR is a pilot of social research toward change and the impact of the change, by providing solutions collaboratively without power differentials between the participants and the researcher(s).

Using PAR as a research design, the study comprised ten co-researchers. They consist of three university management staff, three students' leaders, two security personnel, and two lecturers. These co-researchers were selected using a "convenient selection approach." This approach is relevant because the main assumption associated with convenience sampling is that the members of the target population are homogeneous (Etikan, Musa \& Alkassim, 2016). Therefore, considering the nature of their experiences and involvement in students' unrest and its management enables researchers to make use of participants who are easy or convenient to be approached (Alvi, 2016). Data was generated using Focus Group Discussion (FGD). This was used to implement the tenet of PAR, which predominantly accommodates democratisation, discussion on an equal footing, and inclusivity, among others. This kind of instrumentation is absolutely cooperating with PAR because it enabled the researcher and the researched (co-researchers) to define the problems in contention within the university community and sought to find solutions by means of talking, interrogation, as well as informed strategic actions (Escalada \& Heong, 2014).

Conversational Analysis (CA) was used to make sense of the data generated. The conversational analysis was adopted to enable the researcher to understand the sociality among the co-researchers in order to interpret the relatedness in the university community. This is appropriate because conversation analysis studies the talk produced in human interactions (Nordquist, 2019), which is also called talk-in-interaction as a method suitable for working with audio and video recordings of discussion and social interaction (Sidnell, 2010). That is, CA is a method of analysing an audio and video recorded talks and social interaction to understand and make sense of the sociality involved in the discourse. The issue of ethics relating to this study was observed and received approval from the ethics committee of the University of the Free State, South Africa, with ethical clearance number: UFS-HSD2018/1105. All the participants were given pseudo names in order to protect their personality and were also granted liberty to withdraw from the study at any point in time should they feel any inconveniences. The data is presented below.

\section{Data Analysis and Interpretation}

Data for this study were analysed using conversational analysis, as stated in the methodology. The data were presented based on the derivative themes; Students' Involvement in Decision Making, Democratic and Facilitative Leadership Style that were derived in the participants' conversation and their social interactions under the predominant objective that sort for possible conditions that are necessary for the decolonisation of the minds against modernity as an underside of students' unrest in the university system. The participants were represented with pseudo names as follows; university management staff were represented with UMS1, UMS2, and UMS3; students' leaders were represented with SL1, SL2, and SL3; security personnel was represented with SP1 and SP2 while university lecturers were represented with UL1 and UL2. The results are presented below;

\subsection{Students' Involvement in Decision Making}

Involving students and their leaders in the decision-making process in the university system is one of the ways with which students could be made to see the vision and mission of the university. Not only will it make them see the vision and mission, but it will also encourage them to work towards the actualisation of the university goals and objectives devoid of unrest. Oni and Adetoro (2015) show that one of the conditions needed to ensure effective management of stakeholders in the system is a complementary perspective to decision-making where all stakeholders feel the sense of belonging. That is, university management should, at all times, ensure there is a platform that welcomes the contributions of students and/or its leaders in the management of the system. This, according to Ajayi (1991), opens a mutually constructed dialogue between the authorities and the students. This, in my view, is decoloniality that is needed to deface the underside of modernity in the university system. This is also made known during the focus group discussion with the participants. See below conversations:

SP2: "it should be made known that compromise will be needed from both parties during the decision-making process."

UL1: "No one is coming to the round table solely to give a direct order but disagrees to agree, and agree to disagree."

UMS1: "the student wing within the University community is an important aspect needed not to be toyed with."

SP1: "In implementing decisions, students must be carried along and must also be given a role to play. By so doing, it enables them to give an accurate report back to the colleagues." 
From the conversations, it is clear that inclusive and participatory decision making, discussion and dialogue are inevitable and are ways to which the space of social unrest could be decolonised. This is because the de-colonial approach is presented to deface the leftover of modernity as an invisible power, social and economic structure, and epistemological design to challenge the Euro-North Ameri-centric modern world (Ndlovu-Gatsheni, 2015). Moreover, the party involved must be ready to compromise, meaning that they must be able to shift ground and issues and meet at convenient meeting points. This idea, when implemented, shows that both the parties are compassionate about peace and progress in the university system. In addition to this, the second statement confirms that for peace to reign, there must be a platform where the participants will be allowed to "agree to disagree, and disagree to agree." This could be likened to the decolonisation of the mind (Ndlovu-Gatsheni, 2015). This proposition could only be achieved where all the stakeholders are involved in the decision and/or dialogic process on sensitive issues. From the sociality perspective, the first and the second conversations are on the same page without any classes of egoism and power differentials. Both are on the same plate to making peaceful university environment a priority. This is practically responding to the assumption of Ubuntu, such as; belongingness, inclusiveness, and recognition (Omodan, 2019). This assumption enables subordinates/students to have self-control and self-direction. This, in my view, will satisfy their need for recognition, which will, in turn, reduce the urge of students against authorities.

The third statement bothers on the importance of students in the decision-making process, which is not far from the above analysis. This statement placed necessity on management to not only do all responsibilities but also learn to delegate duties to students. The reason for this statement is based on making students feel recognised in the management of university affairs. This is also viewed from the point that when you are part of the system, you will not work against the system. On the same statements, the last sentence is concerned about how student leaders relay information from university authorities to their fellow students. This could mean that students' leaders will be meticulous in disclosing decisions from management to the students. This is important because if the information is not handled with care, the students may think otherwise against their leaders. Hence, it is not enough to ensure the involvement of students' leaders in the decision-making process of the university, but ensuring adequate representation of all parties is also clamoured for as a means to decolonise the space of social unrest in the system. This is seen below;

SL3 "There should be an adequate representation of the students. The reason behind it is that only a few student representatives are allowed to take part in the decision-making processes of the universities."

SL1: "if management and the few representatives are negotiating, if there is only one student representative, they may not be able to channel their point adequately as they would when there are eight or more student representatives. It becomes easy for management to overpower those students because their voice will have no weight as they are inferior in numbers."

These conversations, from the social understanding, show that the involvement of students in decision making is not enough to adequately ensure smooth management of students' issues. This is because the inclusion of student leaders alone is viewed as a minority because the voice of the minority is usually a no voice in any democratic meeting and/or decision-making process. From this, the decision made from such a meeting may appear to be a pseudo decision cum the underside of modernity. Meaning that, in a negotiating or problem-solving meeting, where minimal students' leaders are present against the whole members of the university senate, the voice of the student leaders may not be heard. Therefore, in implementing this, the management of the universities must find a way around this, to ensure a consistent negotiation and dialogue. This is in line with the recommendation of Odu (2014) that dialogue between students and university authorities through participation in decision making will help $t$ decolonise the space of students' unrest in the system.

\subsection{Democratic and Facilitative Leadership Style}

The kind of leadership adopted by the university management goes a long way in the speedy actualisation of the set predetermined goals and objectives alongside the lifting of modernity to decolonising the system. This also depends on how management is able to respond to issues concerning the stakeholders of the system, including students. This aspect of management bothers on how to motivate and when to motivate students the lecturers, non-academic staff, how to respond to conflict, how to ensure effective communication and teamwork towards the productivity (Babalola, 2018). All these are elements of leadership that are expected to be functioning to make the university environment as peaceful as possible. This is not far from the conclusion of Aldoory and Toth (2004) that leadership is all about empowering stakeholders toward improving organisational productivity. This productivity could only be achieved when there are peace and relative tranquillity in the system. Failure of this by the university organisation had led to many unrests. This, apart from the literature, also reflected in the conversations, as shown below. 
SL2: "Ali-Must-Go crisis, which happens to be the first documented crisis between management and students, arisen because of the undemocratic approach adopted by the university administration, even up till present moment our management are still not improving."

UMS3 "When students are matriculated, they swear a particular oath that they are binding themselves to follow the rules and regulations of the university. That alone gives management the power to with-hold students when they want to oppose management views."

UL1: "Management takes students as people who must do whatever the management thinks is right."

The first conversation shows that the issue of the university style of management from immemorial has been negatively stigmatised. Up until now, the system still remains the same, according to the participants. This not only exists in the experience of the participants. The observation of Ekudayo (2012) and Premium Times (2017) also indicate that university authorities still enjoy a unilateral system of management, which had led to many unrests in schools. The reason for this mindset from university authorities may not be unconnected with the belief shared in the second statement that students are meant to obey every instruction coming from them as a result of matriculation oath made by students on the day they are matriculated into the university community. In short, this belief socially makes students believe that they are not respected by the university authorities. This is actually in contrast to the characteristics of decoloniality of the university system as massive institutions that require dexterous management and scholarly approaches (Keet, Sattarzadeh \& Munene, 2017). However, when there are democracy and facilitative leadership in the affairs of management, this will lead to positive feelings from the other stakeholders. Being democratic and facilitative is good, but not enough if there is no adequate feedback that is commiserating the actions of both parties.

UMS2: "it is not enough to be democratic and facilitative in management but when and only if the suggested ideas brought shouldn't be abandoned, but they should see the result of their ideas when implementation is taking place."

SP2: "the management should ensure constant leadership training that will broaden the mindset of students as to what is expected of them in the society."

These statements confirm the fact that democratic and facilitative management style is good to be used in responding to the issues involving other stakeholders such as students. Also, to make it more robust and make other stakeholders such as students satisfied, it must show some level of sincerity to the implementation of ideas brought up to the management, whether as communication or as agreed upon in a decision making process. This enables students to have trust in the actions and inactions of management towards them. This idea could, therefore, be concluded to be a condition needed to ensure an amicable relationship between students and university authorities. This, as postulated by Ubuntu, is an assumption that could transform the university system to devoid of social unrest. The last statement is of the opinion that student leaders should be exposed to regular leadership training in order to instil in them their social responsibilities as leaders. When this is done, it will also complement the view of management towards the future of the university and the students.

\section{Discussion of the Findings}

The findings associated with the conditions needed to effectively 315 ecolonize students' unrest in universities were presented below. This was done under the following subthemes; Students' Involvement in Decision Making and Democratic and Facilitative Leadership.

\subsection{Students' Involvement in Decision Making}

The above discussion confirmed that students' involvement in the decision making process in both the decision that directly or indirectly concerned students is significant to peaceful relationships. This is to say that to decolonise social space of the universities, the spirit of Ubuntu must be in place to ensure oneness, interrelatedness, and unity of purpose (Anderson, 2003; Omodan, 2019). This, according to Ajayi (1991) and Oni and Adetoro (2015), is needed to ensure effective management of stakeholders by discouraging escalation of possible disagreement. As responded by Ubuntu, this assumption enables the subordinates/students to have self-control and self-direction with the spirit of satisfaction because of its trends towards power equalisation and status differentials between the super-ordinate and the subordinates (Shridhar, 2014). The bridge between these is a Decolonial attempt to equalise power differentials such as the relation of direct, political, social, and cultural domination between students and university authorities (Quijano, 2007). This is thereby concluded to satisfy the subordinates' (students) need for recognition, which will, in turn, reduce the urge for resistance to authorities. This finding is in agreement with the findings of Luescher-Mamashela (2013) that the participation of students in university committees remains the best way to prevent crises on campus. Therefore, students' involvement in decision making is one of the conditions that will 
enable effective decolonisation of students' unrest university system.

\subsection{Democratic and Facilitative Leadership}

It was found that the democratic and facilitative leadership style is good to be used to respond to issues involving all stakeholders in the university system, in particular students. It is also found that to be democratic and facilitative is not enough, but there must be a sense of sincerity in the disposition of democracy and facilitation in governance where there will be transparency in the implementation of agreeable policies and decisions. This, according to Babalola (2018), ensures teamwork towards productivity. This is also in consonance with the finding of Omodan et al., (2018) that there is a significant relationship between the facilitative leadership style and crisis management in Nigerian universities. This means that when leaders are more democratic and facilitative, they make decolonisation of the mind easier and reduce the intention to cause mayhem and unrest by the students. This is also in consonance with the aim of Ubuntu and decoloniality to democratise organisational practices. This, according to Undie (2001), is a bold step to satisfy both the motivational and psychological needs of university stakeholders, including students. Therefore, it is appropriate to say that the practices of democratic and facilitative leadership style in the university system are a condition to effective decolonisation of students' unrest in the university system in Nigeria.

\section{Conclusion and Recommendation}

From the above findings, it was confirmed that the underside of coloniality otherwise known as modernity in the university system is a propeller of students' unrest that has opened the system to unproductivity affecting the actualisation of its aims and objectives. In search to decolonise the system, Students' Involvement in Decision Making, Democratic and Facilitative Leadership styles were found out as practicable dimensions of decoloniality towards peace and social stability in the university system. The decolonisation process could, however, be made achievable with the implementation of the principles of Ubuntu as a transformational agenda that derived its beauty from oneness, love, and unity in diversities. Such a transformation agenda, in my argument, ensure internal and external reconciliation among people, which automatically prevent disagreement cum social unrest in universities.

Based on this, the following recommendations were made; for a manager to be able to effectively manage stakeholders in university where students will have a sense of inclusivity for transformation, the involvement in decision-making and democratic and facilitative leadership style should be maintained and practice by the university authorities. The reconstruction of the university system against social unrest emanating from coloniality/modernity, therefore, becomes expedient by practising "ubuntuism" in the form of social inclusivity and participatory leadership system. This becomes imperative because those elements are agents of peace, tranquillity and transformation; therefore, recommended that to decolonise universities, leaders and or managers should consider those factors as an agent of change, decoloniality, and peace.

\section{References}

Ajayi, OA (1991). Leadership style in institutions of higher education: A contingency approach. Management in Nigeria. A Journal of the Institute of Management, 4(2), 11-22. https://doi.org/10.4236/ojbm.2013.12003

Akparep, J. Y. (2019). An Examination of the Causes of Students-Management Conflicts in University for Development Studies from 1999 to 2009. Open Journal of Leadership, 8, 75-94. https://doi.org/10.4236/oj1.2019.82005

Aldoory, L. \& Toth, E. (2004). Leadership and gender in public relations: Perceived effectiveness of transformational and transactional leadership styles. Journal of Public Relations Research, 16, 157-183. https://doi.org/10.1207/s1532754xjprr1602_2

Alvi M. (2016). A Manual for Selecting Sampling Techniques in Research. Munich Personal RePEc Archive,1-56. https://mpra.ub.uni-muenchen.de/70218/1/

Anderson, A. M. (2003). Restorative justice: The African philosophy of Ubuntu and the diversion of criminal prosecution. South Africa: University of South http://www.ncjrs.gov/App/publications/abstract.aspx?ID=202433

Arthur, D. D., Issifu, A. K. \& Marfo, S. (2015). An Analysis of the Influence of Ubuntu Principle on the South Africa Peace Building Process. Journal of Global Peace and Conflict, 3(2), 63-77. https://doi.org/10.15640/jgpc.v3n2a4

Dube, B. (2016). A socio-religious hybridity strategy to respond to the problems of religious studies in Zimbabwe. Ph.D Thesis, Faculty of Education, University of the Free State. 
Eisenstadt, S. N. 2010. Modernity and modernisation. Sociopedia.isa, 1-36. https://doi.org/10.1177/205684601053

Ekundayo, H. T. (2012). Towards strengthening the relationship between trade unions and university management in Nigeria. African Research Review: An International Multidisciplinary Journal. Ethiopia, 6(2), 266-273. https://doi.org/10.4314/afrrev.v6i2.24

Eric, C. A. \& Urho, P. (2015). Effects of Strike Actions on Educational Management Planning of Universities in Rivers State, Nigeria-Africa. Arabian Journal of Business and Management Review, 3(11), 28-36. https://www.arabianjbmr.com/pdfs/NG_VOL_3_11/3.pdf https://doi.org/10.12816/0017687

Escalada M. \& Heong K. L. (2014). Focus Group Discussion. This article on focus group discussions was written to help agricultural researchers at the International Rice Research Institute in the Philippines conduct focus group discussions with farmers. http://ricehoppers.net/wp-content/uploads/2009/10/focus-group-discussion.pdf retrieved 12/06/2020.

Etikan I., Musa S. A. \& Alkassim R. A. (2016). Comparison of Convenience Sampling and Purposive Sampling. American Journal of Theoretical and Applied Statistics, 5(1), 1-4. https://doi.org/10.11648/j.ajtas.20160501.11

Etadon, F. I. (2013) Campus Conflicts Involving Students' and University Management in Nigeria: The Case of the University of Ibadan, International Journal of Educational Sciences, 5:3, 333-343. https://doi.org/10.1080/09751122.2013.11890094

Faure, G. O. (2000). Traditional conflict management in Africa and China. In Traditional Curses for Modern Conflict: African Conflict Medicine, Ed. Zartman, I. W. Boulder, Colorado, USA: Lynne Rienner Publishers.

Fomunyam, K. G. (2017). Student protest and the culture of violence at African universities: An inherited ideological trait. Yesterday and Today, 17, 38-63. http://doi.org/10.17159/2223-0386/2017/n17a3

Gaus, N. (2017). "Selecting research approaches and research designs: a reflective essay", Qualitative Research Journal, 17(2), 99-112. https://doi.org/10.1108/QRJ-07-2016-0041

Goduka, I. (2000) African/Indigenous Philosophies: Legitimising Spirituality-Centred Wisdoms within the Academy. Central Michigan University, Mount Pleasant. https://doi.org/10.4236/ce.2017.812125

Gunn, S. \& Vernon, J. (2011). The Peculiarities of Liberal Modernity in Imperial Britain, UC Berkeley: GAIA Books. https://doi.org/10.2752/147800414X13802176314960

Hallo, L., Nguyen, T., Gorod, L. \& Tran, P. (2020). Effectiveness of Leadership Decision-Making in Complex Systems. System, 8(5), 1-21. http://doi.org/doi:10.3390/systems8010005

Keet, A. Sattarzadeh, S. D. and Munene, A. (2017). An Awkward, Uneasy (De) Coloniality Higher Education and Knowledge Otherwise. University of Johannesburg and Unisa Press, 12(1), 1-12. https://doi.org/10.17159/1947-9417/2017/2741

Khan, C. \& Chovanec, D. M. (2010). Is Participatory Action Research Relevant in the Canadian Workplace. Journal of Contemporary Issues in Education, 5(1), 34-44. https://doi.org/10.20355/C5PK58

Lassoued, K., Awad, A. \& Guirat, R. B (2020). The impact of managerial empowerment on problem solving and decision making skills: the case of Abu Dhabi University. Management Science Letters, 10, 769-780. http://doi.org/10.5267/j.msl.2019.10.020

Lefa, B. J. (2015). The African Philosophy of Ubuntu in South African Education. Master's Degree article Cape Town: Cape Peninsula University of Technology. https://www.researchgate.net/publication/274374017_The_African_Philosophy_of_Ubuntu_in_South_African_ Education/download, 10/05/2019.

Luescher-Mamashela, T. M. (2013). Student representation in university decision making: good reasons, a new lens? Studies in Higher Education, 38(10), 1442-1456. https://doi.org/10.1080/03075079.2011.625496

MacDonald, C. (2012). Understanding Participatory Action Research: A Qualitative Research Methodology Option. Canadian Journal of Action Research, 13(2), 34-50. https://doi.org/10.33524/cjar.v13i2.37

Marfo, S. (2015). The web: Conflict, peace and security. Unpublished Book.

Mertens, D. M. (2005). Research and evaluation education and psychology: integrating diversity with quantitative, qualitative and mixed methods. London: SAGE publishers. 
Mertens, D.M. (2015). Philosophical Assumptions and Program Evaluation. http://www.spaziofilosofico.it/wp-content/uploads/2015/02/Mertens1.pdf/ 10/04/2019.

Mignolo, M. \& Escobar, A. (2013). Globalization and the Decolonial Option. London: Routlege. https://doi.org/10.4324/9781315868448

Mokgoro, J. Y. (1998). Ubuntu and the law in South Africa.Paper presented at First Colloquium on Constitutional Law, Potchefstroom, South Africa. https://doi.org/10.4314/pelj.v1i1.43567

Ndlovu, M. (2013). Mobilising history for nation-building in South Africa: A de-colonial perspective. Yesterday \& Today, 9, 1-12. http://hdl.handle.net/10394/10513

Ndlovu-Gatsheni, S. J. (2015). Decoloniality in Africa. A continuing search for a new world order. Australian Review of African Studies, 36(2), 22-50. https://trove.nla.gov.au/version/233529126

Nordquist, R. (2019). Conversation Analysis (CA): Glossary of Grammatical and Rhetorical Terms.https://www.thoughtco.com/what-is-conversation-analysis-ca-1689923. 16/02/2019.

Odu O. M. (2013). Management of Students Crisis in Higher Institutions of Learning in Nigeria, International Letters of Social and Humanistic Science, 4(1), 31-39. https://www.ceeol.com/search/article-detail?id=70626 https://doi.org/10.18052/www.scipress.com/ILSHS.15.31

Omodan, B. I. (2019). Defacing Machiavellianism in University Politics: A Discourse to Reconstruct Leadership through Ubuntu. African Renaissance, 16(4), 33-51. https://doi.org/10.31920/2516-5305/2019/16n1a2

Omodan, B. I. \& Dube B. (2020). Towards De-colonial Agitations in University Classrooms: The Quest for Afrocentric Pedagogy. International Journal of Learning, Teaching and Educational Research, 19(4), 14-28. https://doi.org/10.26803/ijlter.19.4.2

Omodan, B. I., Dube, B. \& Tsotetsi, C. T. (2018). Collaborative Governance and Crisis Management in Nigerian Universities: An Exploration of Students' Activism. In M. M. Dichaba \& M. A. O. Sotayo (Ed.), Rethinking Teaching and Learning in the $21^{\text {st }}$ Century, 48-68. Pretoria, South Africa: African Academic Research Forum. https://aa-rf.org/wa_files/saiced-2018-proceedings.pdf\#page $=60$

Omodan, T. C. \& Tsotetsi, C. T. (2019). Framing Ubuntu Philosophy to Reconstruct Principals' Behaviour and Teachers' effectiveness in Secondary Schools. Journal of Education Research and Rural Community Development, 1(1), 30-21. https://jerrcd.org/article/view/19647/13241

Oni, A. A. \& Adetoro, J. A. (2015). The effectiveness of student involvement in decision-making and university leadership: A comparative analysis of 12 universities in South-west Nigeria. Journal of Student Affairs in Africa, 3(1) 2015, 65-81. https://files.eric.ed.gov/fulltext/EJ1127415.pdf https://doi.org/10.14426/jsaa.v3i1.93

Premium Times. (2017). University of Ibadan suspends student union leaders. May 30, 2017.

Ramose, M. B. (1999). African philosophy through Ubuntu. Harare: Mond Books. https://doi.org/10.4236/ojpp.2013.31A017

Richards, H. C. (2015). Modernity's 'other' and the transformation of the university. International Journal of Development Education and Global Learning, 7(2), 6.25. https://doi.org/10.18546/IJDEGL.07.2.03

Sidnell, J. (2010). Conversation analysis: An Introduction. Malden: Wiley-Blackwell. https://www.wiley.com/en-us/Conversation+Analysis\%3A+An+Introduction-p-9781405159005

Sishi, K. K. (2016). Factors influencing Labour unrest: A case of construction employees residing in Quarry Road West informal settlement. Master Thesis, University of Kwazulu-Natal, South Africa.

Stein, S. \& Andreotti, V. D. O. (2016)Decolonisationon and higher education. In M. Peters (Ed.), Encyclopedia of educational philosophy and theory. Singapore: Springer Science+Business Media. https://doi.org/10.1007/978-981-287-532-7_479-1

Swanson, D. M. (2008). Ubuntu: an African contribution to (re)search for/with ' 'humble togetherne's', Journal of Contemporary Issues in Education, 2(2), 53-67. https://doi.org/10.20355/C5PP4X

Taiwo, B. M. (1999). Causes of Student Unrest in Nigerian Higher Institutions. The National Conference Organised on Nigeria Teacher Education of the 21st Century: Attractions and Distractions, Kwara State College Of Education, Ilorin. College Assembly Hall. 13 ${ }^{\text {th }}$-16th April, 1999.

Tsotetsi, C. T. \& Omodan, B. I. (2020). Deconstructing power differentials in a supervision process: Mentoring in 
Ubuntu perspective. Ubuntu: Journal of Conflict transformation, 9(1), 105-129. https://hdl.handle.net/10520/EJC-1d58bd11c1 https://doi.org/10.31920/2050-4950/2020/9n1a6

Undie, J. (2001). Educational Governance. Calabar: Tabson. 